\title{
INTERACTION OF THE EURASIAN ECONOMIC UNION AND ITS MEMBER STATES IN THE SPHERE OF AGRICULTURE
}

\author{
Mark Entin ${ }^{1}$, Dmitriy Galushko ${ }^{2}$ \\ *Corresponding author E-mail: galushkodv@gmail.com
}

\begin{abstract}
A R T I C LE IN F O
A B S T R A C T

Review Article

Received: 15 February 2021

The aim of the paper is to consider the international

Accepted: 19 April 2021 experience of delineating spheres of responsibility of national and supranational regulators in the sphere of agriculture on the example of the Eurasian Economic doi:10.5937/ekoPolj2102491E

UDC 631:[339.923(4+5):061

Keywords:

Eurasian integration, Eurasian

Economic Union, Eurasian

Economic Commission, member

states, agriculture

Union. Used philosophical, general scientific and special methods helped to provide an assessment of the process, which shows that, due to the incompleteness of the process of economic integration, the existing institutional structure of the Union cannot be considered as finalized, and therefore the assignment of certain powers to the Union's bodies is situational, which prevents the formulation of final conclusions on the specifics of delimiting the spheres of responsibility of national and supranational regulators JEL: F02, F15, H79 and the boundaries of powers of national regulators in the agricultural sector. The authors concluded that Eurasian Economic Commission's powers and competence in the sphere of agriculture should be expanded in order to achieve aims of the integration entity.
\end{abstract}

(C) 2021 EA. All rights reserved.

\section{Introduction}

Integration of the Eurasian economic space is one of the key factors that will influence the long-term socio-economic development of the Russian Federation. And the topic of delimiting the spheres of responsibility of national and supranational regulators is one of the key topics for any integration entity, including the Eurasian Economic Union (hereinafter - EAEU). At present, there continues to be observed both duplication of functions of government agencies and services at the national level, and duplication of functions transferred to the supranational bodies at the level of national governments, which retained the relevant structural units. Duplicating functions are usually redundant.

1 Mark Entin, Ph.D., Professor, Head of Department of European Law, MGIMO University, Prospect Vernadskogo, 76, Moscow, Russia, 119454, E-mail: entinmark@gmail.com, ORCID ID (https://orcid.org/0000-0001-9562-8340)

2 Dmitriy Galushko, Ph.D., Associate Professor, Department of Legal Regulation of Economic Activities, Financial University under the Government of the Russian Federation (Financial University), Leningradsky Prospekt, 49, Moscow, Russia, 125993, E-mail: galushkodv@ gmail.com, ORCID ID (https://orcid.org/0000-0002-9301-9565)

http://ea.bg.ac.rs 
Their identification and exclusion from the integration development makes it possible to increase the efficiency of such processes.

The status, place and role of any body of the Eurasian Economic Union is determined by the volume of powers that it is endowed with and actually exercises. The Eurasian Economic Commission (hereinafter referred to as the EEC) plays an important role in the system of the EAEU bodies as a permanent regulatory body of the Union. The composition, functions, powers and procedure for its work are defined in a separate document - «Regulation on the Eurasian Economic Commission» (Regulation, 2014), in accordance with which, the main functions of the Commission are to ensure the conditions for the functioning and development of the Union, as well as the development of proposals in the field of economic integration within the framework of this integration entity (Lapenko, 2017).

\section{Materials and methods}

In order to obtain the most reliable scientific results of the study, philosophical, general scientific and special methods were used to ensure the unity of epistemological, sociophilosophical and legal analysis of the functioning of the Eurasian Economic Union and its interaction with the member states in the sphere of agriculture. The scientific and heuristic potential of such philosophical and general scientific research methods as analysis, synthesis, deduction, induction, abstraction, etc., generalization, modeling, etc. were also used. Thus, the use of methods of analysis and synthesis made it possible to analyze the essence of the Eurasian Economic Commission as the main regulatory body of the Union. On the basis of the system analysis the EAEU measures on regulation of the agricultural sector as well as integrity in unity of its basic components, and also system quality of such measures as an indicator of their efficiency were investigated. Comparative legal and system-structural methods allowed studying correlation between the powers of the EEC and the authorized bodies of the member states. Special methods - legal, classification and grouping - helped to clarify the features and legal mechanisms of such correlation. The dialectical method was used to draw conclusions from the study. The paper's materials were both supranational and national legal acts that define and regulate powers of relevant institutions in the agricultural sector.

\section{Results}

The spheres to which the EEC extends its competence, as a EAEU regulatory body, are very multifaceted. At the same time, this competence is implemented within the «limits of the powers provided for by the Treaty and international treaties within the Union». The existing breadth of the EEC powers, including agriculture, raises the issue of increasing the efficiency of delimiting their spheres of responsibility. When examining the EEC status and powers, it is necessary to keep in mind the existence of an unwritten principle that provides for the EEC's participation in the implementation of many managerial and regulatory functions and decision-making in the form of its own legal acts. 
The Treaty on the Eurasian Economic Union (Treaty, 2014) recognizes the Union as an international organization for regional economic integration with international legal personality (paragraph 2 of Article 1), while securing in the Treaty the EAEU autonomous legal and institutional system (Articles 6, 8) (Chaika, 2020). In the Advisory Opinion of December 20, 2018, at the EEC's request, the EAEU Court stated the supranational nature of the activities of the Union's bodies and the limitation of the sovereign powers of the member states in the relevant areas (EAEU Court, 2018).

The EEC acts, by analogy with law of the European Union, were rightly characterized as acts of a secondary order, and the system of integration law of the Eurasian Economic Union, possessing a number of characteristic features, begins to act as an independent legal order, which is formed according to its own qualifying characteristics and patterns based on generally recognized principles and norms of international law and is different from other systems of law (Iskakova, 2016). The position and status of the EEC as a regulatory body makes it possible to adopt its own regulatory documents and decisions that are of a regulatory nature and binding on the member states. These decisions are included in law of the Union and are subject to direct application on the territory of the member states (p. 13 of the Regulation), which contributes to the effective implementation of the decisions taken (Lukyanova, Plyugina, 2016). The EEC has rather broad powers, but this competence is exercised within the «limits of the powers provided for by the Treaty and international treaties within the Union» (Boklan, Lifshits, 2016), and the decisions taken can significantly affect the economic processes taking place in the EAEU member states. Playing the key role in the EAEU institutional mechanism, the EEC exercises the powers necessary to ensure the coherent operation of the Union's institutional mechanism. Thus, it actively cooperates both with all other EAEU bodies and fruitfully interacts with the relevant competent authorities of the member states. The set of powers granted to the Commission, as well as its role as the main regulatory body of the Union, indicate that in fact this body is the main link, thanks to which the coordination and effective functioning of both legal and institutional is ensured (Sokolova, 2017).

The formation of a common market for goods and services throughout the EAEU is one of the main goals of the EAEU member states. To achieve this goal, a gradual liberalization of certain sectors of the economy, the creation of favorable conditions for the functioning of freedom of trade, which is ensured by reducing and not applying unnecessary requirements, conditions, exemptions and restrictions on the part of the member states, expanding the sectors (subsectors) of the common market for goods and services, as well as harmonization of laws of the member states and the integration entity, are necessary (e.g. Ćemalović, 2016). All these processes are at the stage of development and require analysis to establish a specific approach to the regulation of the agro-industrial complex by the national authorities of member states, in particular Russia, and the EEC, including defining directions for further effective mutual cooperation in the regulation of agriculture as one of the «sensitive» sectors to any integration entity (e.g. Puzić, Klevernić, Pavlović, 2014), as well as to identify main 
problems and challenges for the development of the Eurasian agro-industrial integration (Kiselev, Romashkin, 2020).

The Treaty on the EAEU establishes the following main sectors for the implementation of an agreed (coordinated) agro-industrial policy:

\section{Forecasting in the agro-industrial complex.}

The EEC Collegium approved the new Methodology for forecasting the development of the agro-industrial complex of the countries of the Eurasian Economic Union in June 2020 (EEC Collegium, No70, 2020). According to the new rules the methodology was expanded with forecasting horizons to 5-10 years for medium-term and long-term forecasts with the adjustment of indicators every two years, allowing states and businesses to more fully assess the all-Union trends in the agricultural market and create joint projects.

2) State support for agriculture.

Obligations were taken on the permitted level of measures of state support for the industry, and prohibited measures of subsidizing the agro-industrial complex were determined along with the methodology for calculating the permitted level of state support measures. According to the EEC Department of Agroindustrial Policy, in general, the countries do not violate agreements on measures of state support for the agro-industrial complex.

3) Regulation of the common agricultural market.

At present, the draft Treaty on harmonized rules for the issue, circulation and redemption of warehouse certificates for agricultural products (EEC Collegium, No145, 2020) is under domestic approval. The implementation of its provisions will help to increase the profitability of the EAEU agricultural sector by expanding access to credit resources secured by warehouse receipts, transparency of the turnover and storage of agricultural products, as well as the development of agricultural production and trade. The document will supplement the EEC Board's Recommendation on a coordinated policy in the field of development of exchange trade in agricultural goods (EEC Collegium, 2016).

4) Uniform requirements for the production and circulation of products.

Within the framework of the relevant sectoral agreements, approaches have been determined to unify the requirements for the circulation of seeds of agricultural plants (Agreement, 2017) and the conduct of selection and breeding work within the EAEU (Agreement, 2019).

5) Development of exports of agricultural products and food.

Regarding this issue, we should note the EEC's list of certain types of agricultural products and food for export to third countries (EEC Collegium, No. 25, 2017). While, the EEC powers are limited in this regard to the preparation of analytical and informational materials.

6) Scientific and innovative development of the agro-industrial complex.

In this direction, within the Union, a proper regulatory framework was created for the effective implementation of advanced and innovative technologies and techniques in the field of agriculture. 


\section{7) Integrated information support of the agro-industrial complex.}

In addition to the above directions, the Agreement provides that the Parties will exchange plans (programs) for the development of production of sensitive agricultural products, as well as hold annual consultations on them.

Despite the coincidence of the priorities for the agricultural sector's development, the national regulatory legal acts of the member states in the relevant field do not sufficiently reflect the development of intercountry cooperation in the Union.

In general, the issues of integration of the EAEU countries in the field of the agroindustrial complex are developed by Member of the Collegium (Minister) for Industry and Agroindustrial Complex; EAEU Council for Agroindustrial Policy (includes competent ministers of the member states); Advisory Committee on Agroindustrial Complex (at the level of deputy heads of the authorized bodies of the member states); Working groups under the Advisory Committee on Agroindustrial Complex (with the participation of representatives of the member states); EEC Department of Agroindustrial Policy. The authorized agencies of the member states take part in the EEC advisory bodies in order to determine the priorities for the development of integration and coordinate positions. A big step towards increasing the effectiveness of cooperation was the creation in 2018 of the EAEU Agroindustrial Policy Council, the importance of which as a platform for operational negotiations also manifested itself in a COVID-19 pandemic.

An analysis of the above-mentioned relevant regulatory framework of the agreed agro-industrial policy (in particular, Treaty, 2014; Regulation, 2014; Decision No35, 2013; Decision No94, 2014) makes it possible to form the table below (Table 1), which presents the relationship between the obligations and powers of the EEC and the member states.

Table 1. The relationship between the obligations and powers of the EEC and the member states in the sphere of agriculture.

\begin{tabular}{|l|l|}
\hline \multicolumn{1}{|c|}{ Eurasian Economic Commission } & \multicolumn{1}{|c|}{ Authorized bodies of the member states } \\
\hline \multicolumn{2}{|c|}{ Sensive agricultural products } \\
\hline $\begin{array}{l}\text { Assessment of production indicators, provision } \\
\text { with means of production, customs, tariff and } \\
\text { technical regulation, mutual trade and meeting the } \\
\text { needs of the domestic market, import substitution, } \\
\text { integration potential and export development. } \\
\begin{array}{l}\text { Development of proposals for the sustainable } \\
\text { development of production and increasing the } \\
\text { competitiveness of sensitive goods. Coordination } \\
\text { of development and approval of joint measures. }\end{array}\end{array}$ & $\begin{array}{l}\text { Submission of plans (programs) for the development } \\
\text { of production of sensitive agricultural products and } \\
\text { coordination of actions to the EEC. }\end{array}$ \\
\hline \multicolumn{2}{|c|}{ Forecasting in the agro-industrial complex } \\
\hline $\begin{array}{l}\text { Generalization of national data of the member } \\
\text { states and balancing of foreign and mutual trade. }\end{array}$ & $\begin{array}{l}\text { Calculation of supply and demand forecasts for the } \\
\text { list of agricultural products, raw materials and food, } \\
\text { as the calculation of forecast values and } \\
\text { submission of data to the Commission. }\end{array}$ \\
\hline
\end{tabular}




\begin{tabular}{|c|c|}
\hline Eurasian Economic Commission & Authorized bodies of the member states \\
\hline \multicolumn{2}{|c|}{ State support for agriculture } \\
\hline $\begin{array}{l}\text { Sending a request to the executive authorities } \\
\text { of the member states to provide information } \\
\text { necessary for monitoring and comparative legal } \\
\text { analysis. }\end{array}$ & $\begin{array}{l}\text { Preparation and sending to the Commission and } \\
\text { other member states of a notification on the provided } \\
\text { state support for agriculture for the reporting period } \\
\text { and a notification on planned state support for } \\
\text { agriculture in the current year in accordance with the } \\
\text { forms approved by the Decision of the Council of the } \\
\text { Commission dated October } 18,2016 \text { No. } 163 \text {. }\end{array}$ \\
\hline \multicolumn{2}{|c|}{ Regulation of the common agricultural market } \\
\hline $\begin{array}{l}\text { The supranational competence within the } \\
\text { framework of the Agreement on the Rules for } \\
\text { the Issue, Circulation and Redemption within the } \\
\text { Eurasian Economic Union of warehouse receipts } \\
\text { for agricultural products consists in setting the } \\
\text { requirements: } \\
\text { - to the list of information included in the storage } \\
\text { agreement; } \\
\text { - to the functioning in the member state of } \\
\text { the system of guaranteeing the fulfillment of } \\
\text { obligations under warehouse receipts. }\end{array}$ & $\begin{array}{l}\text { National competences under the Agreement on the } \\
\text { Rules for the Issue, Circulation and Redemption } \\
\text { within the Eurasian Economic Union of warehouse } \\
\text { receipts for agricultural products are to establish the } \\
\text { requirements: } \\
\text { - to the rules of storage and maintenance } \\
\text { of quantitative and qualitative accounting } \\
\text { agricultural products; } \\
\text { - to the form of the warehouse receipt, the procedure } \\
\text { for its manufacture, acquisition, storage and } \\
\text { destruction, types and degrees its protection (in } \\
\text { the case of a documentary form); } \\
\text { - to the formation and maintenance of the state } \\
\text { register of warehouses in the public domain and } \\
\text { registry warehouse certificates. }\end{array}$ \\
\hline $\begin{array}{l}\text { Development of a unified policy in the field of } \\
\text { circulation of seeds of agricultural plants and } \\
\text { pedigree products. }\end{array}$ & $\begin{array}{l}\text { Taking measures aimed at unification of legislation. } \\
\text { Mutual recognition of documents. }\end{array}$ \\
\hline \multicolumn{2}{|c|}{ Development of agricultural exports } \\
\hline $\begin{array}{l}\text { Preparation, together with the member states, } \\
\text { of recommendations for the implementation of } \\
\text { concerted actions aimed at developing of export } \\
\text { potential. }\end{array}$ & $\begin{array}{l}\text { Informing the Commission about: } \\
\text { - the state of international and domestic markets for } \\
\text { exported agricultural products; } \\
\text { - the requirements of foreign countries for the import } \\
\text { of agricultural products; } \\
\text { - applied measures and support mechanisms of } \\
\text { export. }\end{array}$ \\
\hline $\begin{array}{l}\text { Functions within the framework of the Procedure } \\
\text { for organizing joint research and development } \\
\text { work in the agro-industrial complex of the } \\
\text { countries of Union: } \\
\text { - approval of the list of topics for joint research } \\
\text { and development works for } 5 \text { years; } \\
\text { - sending a request for participation to the } \\
\text { government / authorized body. }\end{array}$ & $\begin{array}{l}\text { Functions within the framework of the Procedure for } \\
\text { organizing joint R\&D in the agro-industrial complex } \\
\text { of the countries of the Union: } \\
\text { - formation of an answer (yes / no), determination of } \\
\text { the customer and the contractor; } \\
\text { - development and direction of a feasibility study to } \\
\text { the EEC. }\end{array}$ \\
\hline
\end{tabular}

Source: compiled by the authors on EAEU law, EEC materials and national legislation

Based on the distribution of powers indicated in the above-mentioned table, it can be concluded that the effectiveness of the implementation of the agreed agro-industrial policy depends on two factors: 
- completeness of implementation of norms adopted at the supranational level at the state level;

- completeness and quality of information provided by national authorized bodies to the EEC on time.

\section{Discussions}

An important area of increasing the efficiency of interaction between the national authorized bodies and the EEC is to improve the quality of information interaction, including on the provision of state support and regulatory ensuring. As part of the regulatory mechanism of the common agricultural market, further work will be focused on the implementation of the adopted agreements in the field of circulation of seeds of agricultural plants and breeding products and their further development. An important task remains the adoption at the state level of the Agreement on the rules for the issue, circulation and redemption of warehouse receipts within the EAEU, which will also allow to streamline the regulation of the common market and the distribution of powers between the EEC and national authorized bodies. The agrarian policy of the EAEU countries should also be harmonized. In particular, it is necessary to agree on the application of the same basic support measures for the agro-industrial complex, which distort the market in the least possible way. Otherwise, agricultural producers from different EAEU countries will be in unequal conditions.

The draft Strategic Directions for the Development of Eurasian Economic Integration until 2025 set tasks for the development of integration processes in the agro-industrial sector in order to increase the production of agricultural products and ensure food security. As the basis for a comprehensive document that will determine the general principles and approaches to ensuring food security, the relevant act of the EAEU bodies will be adopted. The Regulation on the development of common principles and approaches to ensuring food security in the Union based on the UN FAO methodology has been supported by all Union countries within the framework of the draft Strategic Directions for the Development of Eurasian Economic Integration until 2025 and should be adopted.

In connection with the completion of the formation in all states of the Union of the regulatory legal framework governing the production and sale of organic products, the EAEU is working to form a supranational regulatory legal regulation in the field of organic agriculture in order to ensure the free circulation of organic products within the Union and the development of exports. Despite the novelty of the legislation in the countries, there are differences in the labeling of organic products, approaches to the regulation of production, certification and standardization, accreditation of conformity assessment bodies. In order to deepen integration, Russia is in favor of developing an international treaty on the creation of a common market for organic agricultural products in the EAEU. 


\section{Conclusions}

As a result of the conducted research, we can conclude that it is expedient to expand the EEC's powers and, accordingly, increase the level of its responsibility. At the same time, there are certain frictions in the EAEU governing system, which are caused by difficulties in coordinating and implementing of the EEC's decisions, because the EEC, as a supranational body, does not have the authority to control the activities of national regulators, and national regulators can influence the EEC only via national governments. Despite the fact that the institutional structure of the integration entity at the initial stage of the EAEU's functioning demonstrates its sufficient efficiency and operability, to ensure the development of integration, it is necessary to add some improvements, in particular, by giving the EEC's Collegium additional powers in agriculture to coordinate the development and implementation of interstate documents in the field of the agro-industrial complex by the allied countries. Moreover, expansion of the EEC relevant powers will contribute to the development of harmonizing and unifying approaches to the regulation and functioning of the agro-industrial complex in all member states of the Union.

\section{Conflict of interests}

The authors declare no conflict of interest.

\section{References}

1. Boklan, D.S., \& Lifshits, I.M. (2016). Operation of the principle of the rule of law in the Eurasian Economic Union. International Law, 2, 1-13.

2. Ćemalović, U. (2016) Harmonization of Serbian national legislation with European Union Acquis - the case of environment. Economics of Agriculture, 63(3), 891904. https://doi.org/10.5937/ekoPolj1603891C

3. Chaika, K.L. (2020). Constitutionalization of Integration Law and Order as a Phenomenon of International Law? International Justice, 1, 67-78. [In Russian: Chaika, K.L. (2020). Konstitucionalizacija integracionnyh pravoporjadkov kak fenomen mezhdunarodnogo prava? Mezhdunarodnoe pravosudie, 1. 67 - 78].

4. EAEU Court. An advisory opinion of December 20, 2018 in the case NCE-2-2 / 7-18-BK on the request of the Eurasian Economic Commission to clarify the provisions of clauses 53 and 54 of the Regulation on social guarantees, privileges and immunities in the Eurasian Economic Union (Appendix N 32 to Treaty on the Eurasian Economic Union of May 29, 2014). [In Russian: Sud EAJeS. Konsul'tativnoe zakljuchenie ot 20 dekabrja 2018 goda po delu N SE-2-2/7-18BK po zajavleniju Evrazijskoj jekonomicheskoj komissii o raz\#jasnenii polozhenij punktov 53 i 54 Polozhenija o social'nyh garantijah, privilegijah i immunitetah v Evrazijskom jekonomicheskom sojuze (prilozhenie N 32 k Dogovoru o Evrazijskom jekonomicheskom sojuze ot 29 maja 2014 goda)]. Retrieved from http://courteurasian.org/page-24731 
5. Iskakova, Z.T. (2016). The system of integration law of the Eurasian Economic Union. Eurasian integration: economics, law, politics, 2(20), 40-44. [In Russian: Iskakova, Z.T. (2016). Sistema integracionnogo prava Evrazijskogo jekonomicheskogo sojuza. Evrazijskaja integracija: jekonomika, pravo, politika, 2 (20), 40-44].

6. Kiselev, S.V., \& Romashkin, R.A. (2020). Agricultural development in the Eurasian Economic Union: achievements, challenges and prospects of the agroindustrial complex. APK: economics, management, 1, 74-90. [In Russian: Kiselev, S.V., \& Romashkin, R.A. (2020). Razvitie sel'skogo hozjajstva v Evrazijskom jekonomicheskom sojuze: dostizhenija, vyzovy i perspektivy. APK: jekonomika, upravlenie, 1, 74-90].

7. Lapenko, M.V. (2017) Organizational and legal basis of the Eurasian Economic Union. Modern Eurasian Studies, 2, 43-58. [In Russian: Lapenko, M.V. (2017). Organizacionno-pravovaja osnova Evrazijskogo jekonomicheskogo sojuza. Sovremennye evrazijskie issledovanija, 2, 43-58].

8. Lukyanova, V.Y., \& Plyugina, I.V. (2016). Institutional foundations of the functioning of integration associations in the Eurasian space. Journal of Foreign Legislation and Comparative Law, 1(56), 78-87. [In Russian: Lukyanova V.Ju., Plyugina I.V. (2016). Institucional'nye osnovy funkcionirovanija integracionnyh ob'edinenij na evrazijskom prostranstve. Zhurnal zarubezhnogo zakonodatel'stva i sravnitel'nogo pravovedenija, 1(56), 78-87].

9. Puzić, G., Klevernić, A., \& Pavlović, Z. (2014). The common agricultural policy through reforms toward Europe 2020. Economics of Agriculture, 61(3), 759-770. https://doi.org/10.5937/ekoPolj1403759P

10. Sokolova, N.A. (2017). Eurasian Economic Union: legal nature and nature of law. Lex Russica, 11(132), 47-57. [In Russian: Sokolova, N.A. (2017). Evrazijskij jekonomicheskij Sojuz: pravovaja priroda i priroda prava. Lex Russica, 11(132), 47-57].

11. Agreement on the circulation of seeds of agricultural plants within the Eurasian Economic Union (Concluded in Moscow on 07.11.2017) [In Russian: Soglashenie ob obrashhenii semjan sel'skohozjajstvennyh rastenij v ramkah Evrazijskogo jekonomicheskogo sojuza" (Zakljucheno v g. Moskve 07.11.2017)]. Retrieved from http://www.consultant.ru/document/cons_doc_LAW_282650/

12. Agreement on measures aimed at unifying the selection and breeding work with farm animals within the framework of the Eurasian Economic Union" (Concluded in Moscow on 25.10.2019) [In Russian: Soglashenie o merah, napravlennyh na unifikaciju provedenija selekcionno-plemennoj raboty s sel'skohozjajstvennymi zhivotnymi v ramkah Evrazijskogo jekonomicheskogo sojuza" (Zakljucheno v g. Moskve 25.10.2019)]. Retrieved from https://www.consultant.ru/document/cons doc_LAW_367428/ 
13. Decision of the Supreme Eurasian Economic Council No35 of 29 May 2013 on the Concept of the Agreed (Coordinated) Agro-Industrial Policy of the Member States of the Customs Union and the Common Economic Space [In Russian: Reshenie Vysshego Evrazijskogo jekonomicheskogo soveta ot 29 maja 2013 g. № 35 O Koncepcii soglasovannoj (skoordinirovannoj) agropromyshlennoj politiki gosudarstv - chlenov Tamozhennogo sojuza i Edinogo jekonomicheskogo prostranstva]. Retrieved from https://www.garant.ru/products/ipo/prime/ doc/70290800/

14. Decision of the Supreme Eurasian Economic Council No94 of 21 November 2014 on the action plan for the implementation of the Concept of an agreed (coordinated) agro-industrial policy of the Member States of the Customs Union and the Common Economic Space [In Russian: Reshenie Vysshego Evrazijskogo jekonomicheskogo soveta ot 21 nojabrja 2014 g. N94 O plane meroprijatij po realizacii Koncepcii soglasovannoj (skoordinirovannoj) agropromyshlennoj politiki gosudarstv-chlenov Tamozhennogo sojuza i Edinogo jekonomicheskogo prostranstva]. Retrieved from https://www.alta.ru/tamdoc/14vr0094/

15. EEC Collegium Order No 70 of 9 June 2020 on approval of the Methodology for forecasting the development of agro-industrial complexes of the member states of the Eurasian Economic Union [In Russian: Rasporyazhenie Kollegii EJeK ot 9 ijunja 2020 goda N 70 Ob utverzhdenii Metodologii prognozirovanija razvitija agropromyshlennyh kompleksov gosudarstv-chlenov Evrazijskogo jekonomicheskogo sojuza]. Retrieved from http://docs.cntd.ru/ document/565070186

16. EEC Collegium Recommendation No19 of 8 November 2016 on a coordinated policy in the development of exchange trade in agricultural goods within the framework of the Eurasian Economic Union [In Russian: Rekomendatsiya Kollegii EJeK ot 8 noyabrya 2016 good N19 O skoordinirovannoj politike v oblasti razvitija birzhevoj torgovli sel'skohozjajstvennymi tovarami $\mathrm{v}$ ramkah Evrazijskogo jekonomicheskogo sojuza]. Retrieved from http://docs.cntd.ru/ document/456023867

17. EEC Collegium Order No145 of 20 October 2020 on the draft Agreement on the rules for the issue (issue), circulation and repayment within the Eurasian Economic Union of warehouse receipts for agricultural products [In Russian: Rasporjazhenie Kollegii Evrazijskoj jekonomicheskoj komissii ot 20 oktjabrja 2020 g. N 145 "O proekte Soglashenija o pravilah vypuska (vydachi), obrashhenija i pogashenija v ramkah Evrazijskogo jekonomicheskogo sojuza skladskih svidetel'stv na sel'skohozjajstvennuju produkciju»]. Retrieved from https://www.alta.ru/ tamdoc/20r00145/ 
18. EEC Collegium Recommendation No. 25 of 14 November 2017 on the formation of approaches to the coordinated export policy of the member states of the Eurasian Economic Union in relation to agricultural products and food [In Russian: Rekomendatsiya Kollegii EJeK ot 14 nojabrja 2017 goda O formirovanii podhodov k soglasovannoj jeksportnoj politike gosudarstv-chlenov Evrazijskogo jekonomicheskogo sojuza $\mathrm{v}$ otnoshenii sel'skohozjajstvennoj produkcii i prodovol'stvija]. Retrieved from http://www.consultant.ru/document/cons_doc_ LAW_283031/

19. Regulation on the Eurasian Economic Commission. Appendix No. 1 to the Treaty on the Eurasian Economic Union [In Russian: Polozhenie o Evrazijskoj jekonomicheskoj komissii. Prilozhenie № $1 \mathrm{k}$ Dogovoru o Evrazijskom jekonomicheskom sojuze]. Retrieved from http://www.consultant.ru/document/ cons_doc_LAW_163855/8e3543f8dc9861d6acfa6a0c6678b972da1d07d0/

20. Treaty on the Eurasian Economic Union, 2014. Retrieved from: https://www.wto. org/english/thewto_e/acc_e/kaz_e/WTACCKAZ85_LEG_1.pdf 
